4. Magaril, S. A. (2016). Smysly patriotizma - istoricheskie transformacii [Meanings of patriotism - historical transformation]. Sotsiologicheskie issledovaniya [Sociological Studies], no 1, pp. 142-151. (in Russian)

5. Natsionalno-patriotychne vykhovannia ditei ta molodi. Normatyvna baza [National and patriotic education of children and youth. Legal basis] (2020). URL: https://imzo.gov.ua/osvita/pozashkilna-osvita-ta-vihovna-robota/natsionalnopatriotichne-vihovannya-ditey-ta-molodi/ (in Ukrainian)

6. Randall Curren, R., \& Dorn, Ch. (2018). Patriotic Education in a Global Age. Chicago, IL: University of Chicago Press.

7. Takeuchi, H. et al. (2016). Differences in gray matter structure correlated to nationalism and patriotism. Scientific reports. URL: https://www.nature.com/articles/ srep29912

\title{
COMMERCIAL SEXUAL EXPLOITATION OF CHILDREN: INTERNATIONAL LEGAL ASPECTS
}

\section{Victoria Melnychuk ${ }^{1}$}

DOI: https://doi.org/10.30525/978-9934-588-39-6-11

Commercial sexual exploitation of children is a serious crime against a child. The problem of commercial sexual exploitation of children is complex and needs to be addressed globally. Today, there are already a number of international instruments regulating the law on crimes related to the commercial sexual exploitation of children. These are, first and foremost, the documents of the United Nations, the Council of Europe, as well as bilateral and multilateral agreements between states, which, by ratifying these agreements, legally undertake to comply with the conditions set out in them.

The issues of legal protection of children who became victims of commercial sexual exploitation were investigated by M. Buryak, A. Vozniuk, I. Dolyanovskaya, M. Kovaleva, L. Kovalchuk, K. Levchenko, Y. Nagachevska, N. Plahotniuk, Y. Smirnov, O. Swed and others.

Commercial Sexual Exploitation of Children (CSEC) is a serious violation of the rights of the child, considered as sex and trafficking; and includes sexual abuse of a child or the exploitation of a child by an adult, as well as payment of cash or in kind to a child or a third party / persons [2, p. 414]. Commercial sexual exploitation of children includes child prostitution,

\footnotetext{
${ }^{1}$ State Scientific Institution «Institute for the Modernization of the Content of Education», Ukraine
} 
pornography and child trafficking. Commercial sexual exploitation of children also includes child sex tourism and early marriages [1, p. 8].

Some researchers have noted that commercial sexual exploitation of children is defined as a form of sexual abuse when a child or third party receives any compensation - in cash or in kind. This definition was also written by the authors of the Declaration and Agenda for Action Against Commercial Sexual Exploitation of Children, adopted in 1996 in Stockholm.

Commercial sexual exploitation of children is a modern form of slavery where children are treated as both sex and commerce.

The United Nations Convention on the Rights of the Child, which came into force on 2 September 1990, has been adopted and ratified by almost all countries, obliging States Parties to take all necessary measures to prevent the child's inclination or coercion to any illegal sexual activity. activities, and to prevent the exploitation of children for the purpose of exploitation in prostitution, pornography or other illegal sexual activities. Article 35 of the Convention requires that all necessary measures be taken to prevent the abduction of children, trafficking in children for any purpose and in any form [3, p. 11].

The Optional Protocol to the Convention on the Rights of the Child on the Trafficking of Children, Child Prostitution and Child Pornography, which came into force on 8 January 2002, pays particular attention to the commercial sexual exploitation of children [3, p. 12].

The International Labor Organization (ILO) Convention on the Prohibition and Immediate Action for the Elimination of the Worst Forms of Child Labor, adopted in 1999, regards the commercial sexual exploitation of children as one of the worst forms of child labor. The ILO Convention requires that ratified States prioritize the development and implementation of an action program to eliminate the worst forms of child labor, and establish and develop appropriate mechanisms to monitor the implementation of the Convention [4, p. 10].

The Council of Europe Convention on the Protection of Children against Sexual Exploitation and Sexual Abuse (2007) sets international standards in the field of preventing and combating any manifestation of sexual abuse of children, protection of the rights of child victims of sexual exploitation and sexual abuse. The Convention includes strict requirements against persons who have committed or intend to commit sexual offenses involving children, including child prostitution, child pornography, child involvement in pornographic performances, seduction of children, sexual harassment [6, p. 13].

It is also worth noting that, at the initiative of the ECPAT International Network of Organizations (ECPAT International), the First World Congress on Combating Commercial Sexual Conduct was held in Stockholm, Sweden in 1996 of child exploitation, which adopted the Stockholm Declaration and Action Plan on Combating the Commercial Sexual Exploitation of Children. 
This document sets out the definition of commercial sexual exploitation of children, confirms the call for improved coordination and cooperation in combating the commercial sexual exploitation of children, outlines measures to be taken to prevent and improve the rehabilitation of affected children. The need to involve children, adolescents and young people themselves in activities to counteract the commercial sexual exploitation of children is emphasized separately [5, p. 29].

In 2001, the Second World Congress Against Commercial Sexual Exploitation of Children was organized in Yokohama, Japan. It adopted the Yokohama Global Commitment under which European countries were called upon to consider, sign, ratify and proceed with the implementation of the UN Convention on the Rights of the Child and the Optional Protocol to the Convention on the Rights of the Child on trafficking in children, child prostitution and child pornography.

In 2008, the Declaration and Call for Action to Prevent and Eradicate Commercial Sexual Exploitation of Children and Adolescents was adopted at the Third World Congress Against Commercial Sexual Exploitation in Rio de Janeiro (Brazil). This document proposes an action plan to prevent, prohibit and end the commercial sexual exploitation of children and adolescents, and provide necessary assistance to children who have been victims of commercial sexual exploitation. Special attention is paid to the problem of using information and communication technologies for the purpose of committing crimes against children. The document also states the need for international cooperation and involvement of the private sector in programs to prevent commercial sexual exploitation [5, p. 29].

Recognizing the global nature of the problem and the fact that a certain category of nationals in different countries resort to sexual exploitation of children abroad, some countries seek to strengthen national law by establishing extraterritorial jurisdiction (ie the status of natural or legal persons exempt from local law and subject to action). the law of the State of their nationality) or the application of existing jurisdiction over crimes against children [7, p. 103].

The legislation of different countries on combating sexual exploitation and sexual abuse of children shows the variety of legislative strategies and forms of response to this problem. However, it is obvious that the achievement of the result is possible through the application of a comprehensive approach, namely the establishment of appropriate legislative provisions aimed at preventing sexual exploitation of children, effective prosecution and prosecution and protection of the rights of child victims.

Commercial sexual exploitation of children in a number of countries today has become one of the areas of particularly dangerous criminal activity, 
violations of the rights of the child. Therefore, this problem requires constant monitoring and thorough study. And an important step in its resolution was the adoption of a number of international instruments regulating the legislation on crimes related to the commercial sexual exploitation of children (UN Convention, Council of Europe, bilateral and multilateral agreements between states).

Despite international standards, according to which the responsibility for child prostitution rests with those persons who have engaged them in such activities, or those who use such services, this issue needs constant monitoring by international organizations, legal structures and public authorities.

Today, many interested organizations, people work around the world, working hard to counter the commercial sexual exploitation of children.

\section{References:}

1. Buryak, M. Y. (2005). Trafficking in human beings and combating it: criminological and criminal-legal aspectst. Vladivostok, p. 26.

2. Gurvich, I. N. (2014). Commercial Sexual Exploitation of Minors in the Modern World. Mirror of Sociology: Collection of Articles. St. Petersburg, pp. 412-443.

3. Dolyanovska, I. M. (2008). Criminal responsibility for the exploitation of children (analysis of the crime). Criminal Law and Criminology; Criminal Enforcement Law. Kyiv, p. 18.

4. Plahotniuk, N. V. (2002). International legal aspects of combating trafficking in women and children. International Law. Kyiv, p. 20.

5. Rogova, I. G. (2014). Formation of norms of international law on responsibility for trafficking in human beings. Science and education: economy and economy; entrepreneurship; law and management, pp. 28-30.

6. Smirnov, Y. P. (2010). Criminal liability for sexual exploitation of other persons in the form of prostitution. Moscow, p. 29.

7. Strengthening Laws addressing child sexual exploitation: practical guide / ECPAT International (2008). 